\title{
EDITORIAL APPROACH AND CONVENTIONS
}

Our translations attempt to follow the medieval Latin closely, providing editorial glosses within the text or footnotes where this may help to clarify. Additions within pointed brackets $-<>-$ indicate conjectural expansions of the texts. Additions within square brackets indicate editorial glosses and clarifications: those italicised are editorial comments, those unitalicised are alternative translations, biblical references or a citation of the original Latin of the document. Any text in rounded brackets is part of the original document itself (though the brackets themselves are not).

We have annotated some, but by no means all, named individuals in the documents; given the vast numbers of people named in the deposition records, the reader is better served by the index, where we have listed prominent figures and those who appear in several different texts. The modern equivalents for the Latin place-names in the inquisition records of Languedoc have been found with the help of the lists in Saisimentum Comitatus Tholosani, ed. Y. Dossat (Paris, 1966) and M. François, Ch.-E. Perrin and J. de Font-Réaulx, eds, Pouillés des Provinces d'Auch, de Narbonne et de Toulouse, 2 vols (Paris, 1972), and the locations in the Institut Geographique National's CD-ROM Dictionnaire des Toponymes de France and 1:2500 maps. We warn the reader that there is sometimes uncertainty in these identifications, that the same place-name is often used for several places, and that some famous regional place-names (for example, Aragon and Paris) are also the names of places in southern France.

Biblical translations are taken from the Douay-Rheims translation of the Bible, following its recommendation by Beryl Smalley, who knew medieval readership of the Bible better than any other modern scholar. ${ }^{1}$ We have used the following additional conventions:

- Italics are used to pick out quotation or allusion in texts and for unidentified place-names.

1 See also The Practice of the Bible in the Middle Ages: Production, Reception and Performance in Western Christianity (New York, 2011), p. 5: 'it preserves in English the sense that would have been known to most medieval readers of the Latin Bible'. The Bible text is accessible at www.drbo.org. 
- Italics are also used in Part VII (Docs 33-40) to pick out terms describing types of heretic and suspect, which are discussed or defined in those texts.

- We have left castrum/castra in italics, in Latin, rather than translating as 'castle/s', because castrum in southern France usually indicated a fortified town or village.

- For translations from manuscript documents (and some lengthier edited documents) in the 'Depositions' section, we have included folio numbers (fol., fols) - like this: /261r/ - to allow the reader to cross-refer to other modern scholarship on these materials, indicating the front and back of each folio with ' $\mathrm{r}$ ' (for recto) and ' $\mathrm{v}$ ' (for verso).

- We have presented female first names as they appear in documents, but translated male first names into English where possible. ${ }^{2}$

- Titles - bishop, lord, count, inquisitor etc. - are capitalised when applied to a specific person.

- We have not followed the technical abbreviations used by specialists on canon law, ${ }^{3}$ but have specified 'Case, question, chapter' when referencing Gratian's Decretum.

2 See the discussions of female and male first names in J. H. Mundy, Men and Women at Toulouse in the Age of the Cathars (Toronto, 1990), pp. 39-40, and Inquisitors and Heretics, pp. 124-7.

3 For which, see J. Brundage, Medieval Canon Law (Harlow, 1995), pp. 190-205. 